\title{
World libraries, the role of cultural agencies
}

Juan José Prieto Gutiérrez, Complutense University Library, Ciudad Universitaria. Facultad de Derecho. Biblioteca, E-mail : jipg@ buc.ucm.es

\begin{abstract}
Cultural actions are one of the best tools for ministries of foreign affairs worldwide. Many countries who choose to work with cultural actions could potentially reach millions of citizens, inclusive of those living in remote areas. One of these cultural actions is that of establishing and opening cultural centers. This paper presents libraries as providing outstanding service in all these centers. Through a historical and numerical analysis of the libraries of The British Council, the Alliance Française's Institut Français, the Goethe Institut and the Cervantes Institute, it can be shown that libraries are a real tool for public diplomacy that can exceed its remit of social assistance, social services and education. To conclude this paper will also look at actions that could be undertaken to improve and cater for network libraries.
\end{abstract}

Key words: information, public diplomacy, information access, public information, libraries

\section{Introduction:}

Cultural actions in the field of international relations offer effective benefits. Many researchers, such as J. Nye Jr. (2009), ${ }^{1}$ defend them, as does a large percentage of related sector professionals, for instance B.H. Signitzer and T. Coomb (1992), ${ }^{2}$ N. J. Cull (2008), ${ }^{3}$ Institute of Cultural Diplomacy (2011). ${ }^{4}$

An essential line of the cultural diplomacy practiced by many countries from the late nineteenth century on (e.g. the Alliance Française as of circa 1883) is the development of cultural and linguistic network centers around the world. These have adapted to the needs and interests of people in their host countries. In historical terms, by their presence and actions, the British Council, the Alliance Française, the Institut Français, the Goethe Institut, the Cervantes Institute, and the Camões and Confucius Institutes have been very active in many countries. Other countries have opted to downplay cultural practices and emphasize other assets, such as military force. The most noted decrease in cultural practices has been in the USA (Ninkovich $1981 ;^{5}$ Arndt $2005^{6}$ ).

All of the cultural institutes mentioned focus on the study and promotion of the language and culture of their home countries outside of their own national borders. The core business of these network centers lies in offering different services to local citizens: exhibitions, publications, interviews, corporate reporting, and official functions which are documented within the social media and so on. Next to this, they run libraries 
that are open to regularly enrolled students as well as to the public at large. These libraries offer a wide range of services, including multiple technological services working together and creating a very unique and special environment. As strategic communication instruments the role of the libraries is based on the public diplomacy aim to "understand, inform and even influence public decisions" (Krause, P.; Van Evera, S., 2009). ${ }^{7}$

The article will try to show the value of the libraries owned and run by the British Council, the Alliance Française and the Institut Français, the Goethe Institut and the Cervantes Institute. Together they offer approximately 1.600 libraries to a million people from over 100 different countries. These spaces may be considered as public libraries since they meet the International Federation of Library Associations and Institutions IFLA/UNESCO Manifesto definition which stipulates equality of access for all, regardless of age, race, sex, religion, nationality, language or social status. ${ }^{8}$ The twelve missions laid down in the Manifesto include the creating and strengthening of reading habits in children, supporting education, providing opportunities for personal development, fostering inter-cultural dialogue, and favoring cultural diversity. However, these 1.600 libraries not only provide and lend books; they also function as instruments of public diplomacy.

\section{Historical Overview}

The British Council was founded in 1934, operates in 110 countries and has more than 200 branches, managed by 7 Regional Directors. It finds its origin in the political and social situation in Europe in the first third of the twentieth century. From the beginning, the British Council has set out to build mutual cultural and educative relations between the United Kingdom and other countries, mainly through cultural propaganda and English language instruction. Different types of resources and services, both indoor and outdoor, are on offer to local communities. The libraries, located inside the centers, provide support for language learners, offering a wide range of teaching resources as well as the best of British cinema and British literature, charity events, training for teaching, translation of literary works, student scholarships, grants, etc. Political changes in the field of foreign affairs have brought about modifications in the management of the centers. Since the 1990s the BC seeks to assist citizens, leading the way instead of solely creating iconic public locations.

In early 2015, the British Council (BC) retained only 15 libraries, defined as open and free public spaces dedicated to provide and offer information, in any format, in four countries outside of the UK, these being India, Bangladesh, Sri Lanka and Myanmar (Burma). It also runs more than 170 schools, study centers, self-learning centers and resource centers which are locally called 'libraries', as they keep a variety of documents but they are essentially meant for students, teachers and other specific groups; however these are not considered as libraries by the BC in London. Indeed, these centers do not have a network of libraries and library departments in London as was the case until some years ago. For this reason global statistics such as the total number of users, loans, documents, budget, actions, etc. are not available. The reality is that sometimes centers do not report their statistics. At a management level, each center Director is fully responsible for safeguarding the libraries, documents and record locations within his or her center. A Director is independent from London headquarters. This setup leads to 
there being large differences between libraries. Even though there is no standard for evaluating them, all of them remain under BC general supervision and occasionally limited and specific activities run by various BC libraries have been shared in the same city or country. In essence, the future of library growth is in developing digital libraries to reach out to people everywhere, including remote locations. Hence the plan is to increase the investment in digital and network resources, so that more and more people can register and make use of what is on offer online.

The foreign cultural action of France involves a large network of centers. These perform through two operators working in a coordinated way under the responsibility of the Ministry of Foreign Affairs. The two institutions are the Alliance Française (AF) and the Institute Français (IF). The French network is the most effective of all created cultural instruments and assets. For this reason it has been an inspiration to many countries that wish to improve international relations through cultural connections.

The Alliance Française, founded in 1883, is the oldest and largest international cultural network, with more than 1.400 centers. The Alliance Française centers are civil society associations, non-profit, managed by a common board of local French-speaking people whose main and vital objective is teaching the French language and the spread of French culture. Not all the network centers have a proper library, but all the centers offer rooms or spaces with materials and books for learning the French language. The biggest centers maintain large and well-documented utilities with multiple services for reading, learning, cultural exchange and immersion in French life. The heterogeneity of the services and facilities offered sometimes leads to staff choices whereby librarians are not available, or not available all the time, and in some cases even the maintenance of the documentary heritage is jeopardized. Nevertheless, there are large centers such as that in New Delhi with four librarians (two belonging to the AF and two the IF). Sometimes the library is attended to by a student. At other times it is a teacher who strives to keep up the collections and services, or a volunteer or suitably trained worker. Due to their varied experience and the heterogeneity of management this usually generates a reduced log of statistical information. Even so, it should be said that all centers, both those which have libraries and those with only reading rooms, are multicultural, free and open areas, with the possibility of access to all citizens.

The Institut Français is the "official" operator of the French Ministry of Foreign and European Affairs that is responsible for the promotion of French culture and language worldwide. It is also the most commissioned because the IF has taken over the cultural departments of embassies, becoming a kind of a "public establishment of industrial and commercial character" (EPIC). Founded in 1907, the IF currently has more than 150 centers across the world, and is the main asset of French cultural diplomacy. To achieve its objectives, the IF provides a wide range of services to the local community, ranging from language teaching to conferences and translation assistance, to libraries and in some centers even a theater. Libraries, or "mediatheques" as they are called by the organization, operate as a real network and organically depend on a central unit office located in Paris. They are placed under the Department of Paper and Promoting Knowledge. These libraries not only lend books and documents for learning the French language or to promote the country, they also perform services to institutions and professionals, cultural activities, subsidize translations of documents from the local language into French and vice versa. They offer theater plays, screen films, hold interviews and book launches. 
The end of World War II forced Germany to restore confidence and credibility abroad. For that reason it was necessary to reconstruct its international relations without compromising its culture. In order to meet this objective, since 1945 various cultural sector initiatives have functioned as important assets to the country's foreign policy. Among the most important figures the Goethe Institut, established in 1951 as successor to the Deutsche Akademie, which dated back to 1925. The headquarters of the Goethe Institut is in Munich, and in order to manage the budget efficiently the institute divided the planet into 12 geographical areas, each with its own center and managing Director. From the very foundation of the Goethe Institut, the Goethe libraries have been crucial to the Institut's strategy. There are 96 libraries which primarily aim at "giving a comprehensive image of Germany by providing information on the cultural, social and political life" through its documents and services, while serving to support German students.

The Cervantes Institute is a worldwide Spanish cultural institution founded in 1991. The importance of the Spanish language in the world and the appreciation of its culture generated the need for international centers around the planet, on a par with other European countries. The Spanish language and its culture is the strongest and most reliable asset that the country has. Therefore, the implementation and extension of the institution is a necessity. Cervantes Institutes (CI), like their counterparts, offer a variety of services and instruments that seek to meet the organization's objectives. One of them, the library network of the Institute, began to take shape in 1992, with a library opening in each center. The CI libraries are supported by a headquarters in Madrid.

At the end of 2014, 63 libraries were in operation, run by a total of 80 people. Both the libraries and documentation departments are well defined. A specialised manager located in Madrid is responsible for the organization. This professional is helped by a skilled and experienced team. Depending on the size of the library, its funds and the services it offers, in each of the 63 places around the world the CI employs 1 to 3 librarians. Over $90 \%$ of these librarians are Spanish, becoming expats as they take up their positions abroad.

Cervantes "Aulas" are places which are dependent on the CI and which have been created since 2000 as an alternative to "real" CI centers. They are more flexible, and above all require less of a budget to run. Usually they are located in universities to contribute and help enhance the way the Spanish Department works in that university or college. They do this by offering such things as training to teachers, providing teaching materials, providing spaces for teaching, conducting cultural activities, etc. All the Cervantes Aulas mainly offer documents and materials for learning to speak and read in Spanish and about Spanish culture. The size of these centers may vary according to the resources and spaces offered at each university. 


\section{Libraries in figures}

As has been remarked, the diversity and accuracy of the statistics available vary from one center to another. As will be seen below, those centers which have library Departments usually process analyses and annual statistical data and vice versa. Table 1 shows the most relevant statistical information for the 1600 libraries of the four cultural centers.

Table 1: Numbers

\begin{tabular}{|c|c|c|c|c|}
\hline & $\begin{array}{l}\text { British } \\
\text { Council }\end{array}$ & AF/IF & $\begin{array}{l}\text { Goethe } \\
\text { Institut }\end{array}$ & $\begin{array}{l}\text { Cervantes } \\
\text { Institut }\end{array}$ \\
\hline $\begin{array}{l}\text { Presence } \\
\text { - Countries } \\
\text { - Centers }\end{array}$ & $\begin{array}{l}110 \\
200\end{array}$ & $\begin{array}{l}161 \\
1073(\mathrm{AF})+ \\
144(\mathrm{FI})\end{array}$ & $\begin{array}{l}95 \\
160\end{array}$ & $\begin{array}{l}43 \\
86\end{array}$ \\
\hline $\mathrm{N}^{0}$ libraries & $15^{*}$ & $\begin{array}{l}143 \mathrm{IF}(\mathrm{x} \\
\text { countries })+ \\
1073 \mathrm{AF}(136 \\
\text { countries })\end{array}$ & 96 & 63 \\
\hline Users & $90.000 * *$ & 185.522 & 54.000 & 81.000 \\
\hline Visitants & unknown & 450.000 & 816.000 & 966.000 \\
\hline Documents & $350.000 * *$ & 3.330 .000 & 903.000 & 1.250 .000 \\
\hline Loans & $1.140 .000 * * *$ & 4.260 .000 & 805.000 & 710.832 \\
\hline Budget & $\begin{array}{l}165 \mathrm{k} \\
\text { GBP**** }\end{array}$ & $3.611 .792 €$ & unknown & unknown \\
\hline Cultural activities & 12.700 & unknown & 5.800 & 5.300 \\
\hline
\end{tabular}

* The British Council has only 15 libraries. (9 in India, 1 in Bangladesh, 1 in Myanmar [Burma] and 3 in Sri Lanka). The other centers have learning centers, study centers, self-access centers or resource centers which are much smaller and usually attached to teaching centers.

** Only fifteen libraries in India, Bangladesh, Sri Lanka and Burma.

*** Only India British Council.

**** Only Bangladesh British Council.

\section{Library services}

There is no doubt that the services offered by the four institutions center upon teaching their own home country languages and the dissemination of their own culture. The 
"basic" or traditional services provided by the four centers are lending services, reference services, bibliographic information, home loans, Internet, training, reading groups and conversation clubs. In addition they offer other services that often transcend the objective of a "public" library. Overcoming the physical barriers of the buildings themselves, they offer services to citizens and even assistance in priority areas for community development, such as editing documents, the promotion of local writers and artists, collaboration with local institutions for the dissemination of literature and publications, sponsoring study grants, counseling areas, performance of plays, multicultural services with local agents and free access to the internet in areas with limited or restricted access.

The British Council runs educational programs in countries such as Sri Lanka, India, Pakistan, etc. In Myanmar (Burma), for instance, about 70,000 people per year use the BC facilities, especially its library service. In Zimbabwe, about 50,000-60,000 people per year visit the BC offices in Harare and Bulawayo, where the aim of the Council is to provide support and assistance to young professionals who wish to stay and work in Zimbabwe. In 2005 the BC sponsored the first Shakespeare production in Afghanistan, put on by local actors, both men and women. In addition to this, competitive sport events, especially soccer, have also been held to attract young people in the Middle East. In Iraq, journalists have been trained and in Pakistan the BC works and collaborates with many madrassah.

The Institut Français has instituted a library bus project in Düsseldorf. In many countries IF has financed, published and printed documents translated from the local language into French and vice versa. IF supports a collaboration between French artists and local artists, in fact its libraries offer much documentation for encouraging this process. The African Film Library keeps one of the largest collections of African films from the 60 s to date. The library preserves the manuscript collection of the Shaiva Siddhanta (the most important religious tradition of Hinduism in South India) which is the largest manuscript collection of its kind worldwide.

The Goethe Institut provides aid to German librarians and experts worldwide. It offers assistance with the organisation of field trips and general support and assistance to German expats and residents wherever a center is located. The institution also provides mobile libraries to reach the vast population of Johannesburg. Over 100 buses cruise the suburbs providing assistance to schools and citizens. Volunteering is offered (in some local libraries), next to assistance and collaboration to the local publishing sector. In 2012 the Goethe Institut funded a survey of the publishing sector in Sub-Saharan Africa.

The Cervantes Institute runs activities for kids in Sydney, training for local librarians (in a few branches), interviews, introductions and presentations to local writers, as well as workshops and scholarships for Chinese students. In addition, the CI encourages publication of teaching materials and collaborates with institutions in providing research materials.

In most cases these services are aimed at young professionals, students, scholars, government agencies and non-governmental organisations, ultimately covering a wide range of ages. These services which are carried out by many of the libraries show that they closely assist local citizens to satisfy the needs and shortcomings that may exist in areas where they are established. 


\section{Conclusions}

There is no doubt that the libraries of the four cultural and language centers analyzed (British Council, Alliance Française and Institut Français, Goethe Institut and Cervantes Institute) are a fantastic asset of public diplomacy. They play an essential role in supporting citizens and communities, providing access to the world through language. Finances for these libraries are usually tight as they are budgeted by the Ministries of Foreign Affairs of their respective countries. This forces the libraries to seek external financing and sponsoring from private companies and/or through other forms of fundraising. There is no doubt that the financial trend of all four analyzed groups is toward a self-financing system without government administration backing.

The approximately 1,600 libraries of the cultural institutions examined show exceptional public service, focusing on supporting the greatest number of local citizens wherever the centers are situated. It is vital to help these centers develop and thrive, not only for those who want to learn or improve their knowledge of a foreign language but also to keep such important resources active within communities around the world. Being provided with multiple services, such as internet access, financial aid, scholarships and counseling, a community is offered opportunities to move forward easily. An example of having a lack of support is seen in the work of Seoul's Goethe branch in North Korea, which due to limitations of freedom of expression, information and communication had to close its doors only a few years after opening, in 2009. To reinforce or even improve the service of libraries, not just to the public that uses them but also for those responsible for these cultural centers such as staff, and those working in the Ministries of Foreign Affairs, it would be necessary that all institutions organise their libraries network to run with optimal management. It would also be advantageous to set up a global network focused on libraries of all cultural and linguistic centers within the European Union National Institutes for Culture (EUNIC); and it would be beneficial to create a section in IFLA for the purpose of defending the collective interests of their libraries in the cultural and linguistic centers. After all, as has been demonstrated above with numbers and actions, these libraries are what is most valued and used by the citizens. These institutions reach out beyond their natural fields in order to meet the needs of the citizens and the general public. As such, these libraries stand as an example of a brilliant instrument for foreign policy action in many countries.

\footnotetext{
${ }^{1}$ Nye, J., Jr. (2009) Get Smart- Combining Hard and Soft Power, Foreign Affairs 88(4) (July/August 20 2009), 160-63.

${ }^{2}$ Signitzer, B. H., and Coombs, T. (1992) Public relations and public diplomacy: Conceptual convergences, Public Relations Review 18(2), 137-147.

${ }^{3}$ Cull, N. J. (2008). Public diplomacy: Taxonomies and histories, The annals of the American academy of political and social science 616(1), 31-54.

${ }^{4}$ Institute of Cultural Diplomacy (2011) Cultural diplomacy outlook report 2011, available at: www.culturaldiplomacy.org/culturaldiplomacynews/index.php?en_cd-outlook-2011_content (accessed May 7, 2012).

${ }^{5}$ Ninkovich, F. (1981) The Diplomacy of Ideas: US Foreign Policy and Cultural Relations, 1938-1950 (Cambridge: Cambridge University Press).

${ }^{6}$ Arndt, R. (2005) The First Resort of Kings: American Cultural Diplomacy in the Twentieth Century (Washington, DC: Potomac Books).
} 
7 Krause, P. and Van Evera, S. (2009) Public Diplomacy: Ideas for the War of Ideas, Discussion Paper 09-10 (Belfer Center for Science and International Affairs, Harvard Kennedy School, 2009).

${ }^{8}$ IFLA, U. (1994).

\section{About the autor}

Juan José Prieto has published 5 monographs and more than twenty articles. Some more recent publications: Safeguarding bibliographical heritage. The library of the 'Institut d'Égypte' in Cairo, Forum UNESCO-University and Heritage (FUUH). No 85, 2012 ISSN: 1887-1372; Bibliotecas digitales: seguridad en el modelo de referencia OAIS, World Library and Information Congress: 78th IFLA Congress. Congress Proceedings. Helsinky, Finland. August 2012 (with Barbara Muñoz de Solano y Palacio and Fernando Ramos Simón); Herramientas para el análisis y monitoreo en Redes Sociales, IRIE, International Review of Information Ethics. (Ethics of Online Social Networks). Vol. 16 - December 2011. ISSN: 1614-1687. 